\title{
Sounding salvation: Theological perspectives on music as articulation of life
}

\author{
JCILLIERS ${ }^{1}$
}

\begin{abstract}
This paper proposes some theological perspectives on the phenomenon of sound (i.e. music), linking it to the gospel of salvation (i.e. well-being). Possible links between sound and music; sound and life; sound and silence; and sound and salvation are indicated. Some differences between the Western and African understandings of sound, music and life are highlighted; followed by suggestions concerning the connections between salvation, well-being, and the healing of life. A theological understanding of music as an expression of transcendence and anticipation is given, profiling it as a distinct form of hope. The paper concludes by comparing two iconic paintings that depict sound: The Scream by Edvard Munch and The Tortured Christ by Guido Rocha.
\end{abstract}

Keywords. Sound, music, silence, life

\section{Sound Beginnings}

The father of psycho-analysis, Sigmund Freud, once told the story of a little girl who was afraid of the dark. It was bed-time and she was alone in her room, with the nanny sitting in the room next door. The girl cried out: "Auntie, talk to me, I'm frightened", whereupon the nanny answered: "But what good will that do? You can't see me." The child replied: "If someone talks, it gets lighter."

Words create worlds; voices form spaces of comfort and grace, but also chaos and darkness. Sound - the sensation produced in the ear or other organ of hearing by the vibration of the surrounding air or other medium - is a multi-layered concept that can manifest in various

1. Johan Cilliers is Professor in Homiletics and Liturgy at the Faculty of Theology, Stellenbosch University.jcilliers@sun.ac.za

2. Sigmund Freud, A General Introduction to Psychoanalysis (New York: Boni and Liveright, 1920), 17. 
ways and be analysed as a phenomenon within a broad spectrum of scientific fields. Research on "the sound of worship" still seems to be in its infant stages. ${ }^{3}$

The sound of the voice has always played an important role in African culture. ${ }^{4}$ As a matter of fact, in the South African language isiXhosa the same word is used for "word" and "voice" (Ilizwi). In Africa words are not primarily meant to be put on paper, but to live in the air, the space between people. It in fact creates these spaces between people. It has been noted that sounds like calls, cries, and shouts were used by African Americans in the plantations (where they were forced to work as slaves) to convey warnings, to break monotony, to summon help, to encourage; in fact to express deeply felt emotional and physical experiences, such as loneliness, homesickness, and hunger and thirst. ${ }^{5}$ In short, the sense of sound should not be underestimated; the vitality of the voice not trivialized.

The most intimate moments of life cannot be articulated only in words; they must be expressed - and heard - in sounds. When a mother in Africa sings a lullaby to her infant (Tula Tu Tula baba, Tula sana Tul'umam 'uzobuya ekuseni) the words are not the dominant factor in comforting the child (although the words are not unimportant), the sound of her voice is. ${ }^{6}$ The words form the vehicle that carries the sounds of soothing; that facilitates the tones of nurturing. The words take a step back behind the sounds, they rather work sub-consciously. The oral and acoustic dimensions of the lullaby create intimacy, an intimacy that celebrates and fosters the life embodied in the baby. The meaning of (this) life is acknowledged and created in the expression of the song in sound. The sound of the voice ties the significances, the spectrum of meanings together, long before words are understood. Indeed: In the beginning was... Ilizwi, the Word that is the Voice. ${ }^{7}$

\section{Singing Life}

Life is seldom better expressed than in music. Words alone are not enough. Music is needed - as an intensified form of words; as concentrated meaning. In short: music is one of the most existential expressions of life in sound. The most intimate moments of life cannot be articulated only in words; they must be expressed - and heard - in sounds.

It is clear that there are fundamental links between singing and life. As a matter of fact, singing is (a mode of) life, an expression of the existential dimension of life. This fundamental link entails, inter alia, the following: singing as immediacy of experience; singing as hermeneutics, i.e. as mode of giving meaning; singing as acoustic expression of meaning;

Cf. the excellent work done by the Dutch liturgist Mirella Klomp, The Sound of Worship. Liturgical Performance by Surinamese Lutherans and Ghanaian Methodists in Amsterdam (Leuven: Peeters Press, 2011).

4. Actually one cannot speak of African culture in the singular. Africa is a vast continent, incorporating a wide variety of cultures and ethnic groups. Northern Africa differs totally from Southern Africa. The term "Africa" does not denote one homogenous group.

5 . $\quad$ Klomp, The Sound of Worship, 54-55.

6. Music was called "sound-speech" (Klangrede) as far back as 1739, for instance by Johann Mattheson, Der vollkommene Capellmeister (Hamburg, 1739), 17, 25.

7. Cf. Johan Cilliers, Faith in search of sound: The interaction between religion, culture and hymnology. Vir die Musiekleier 2011; 31: 3-19. 
singing as language and articulation (verbalization; verbal expression); singing as symbolization (giving symbolic meaning to convictions); singing as worship and confession; singing as ritual (liturgical dimension); singing as lament (voicing of suffering); singing as joy and gratitude (mystical unification with the transcendent); singing as spirituality (and therefore: shaping of God-images), etc.

Because singing is a spiritual exercise it relates human beings to the sacramental dimension of life; life being the metaphor and symbol of God's presence within the events of daily life. Singing is clearly linked to religious experience and expression. In both the Lutheran and Reformed traditions - to name but two - music plays an important part in worship. Luther accepted music as part of the true church, and as an expression of faith itself. ${ }^{8}$ Calvin referred to music as "sung prayers". 9

\section{An Icon of Sound}

We tend to think that an icon exclusively implies an image, but sound was also understood as an icon, as early as the Byzantine era. ${ }^{10}$ A sacred space like the Hagia Sophia is a striking

There are many delightful references to music by Luther, for instance: "Next to the Word of God, the noble art of music is the greatest treasure in the world! The riches of music are so excellent and so precious that words fail me whenever I attempt to discuss and describe them.... I most heartily desire that music, that divine and precious gift, be praised and extolled before all people.... Experience proves that, next to the Word of God, only music deserves being extolled as the mistress and governess of the feelings of the human heart... A greater praise than this we cannot imagine... I truly desire that all Christians come to love and regard as worthy the lovely gift of music, which is a precious, worthy, and costly treasure given to mankind by God... It controls our thoughts, minds, hearts, and spirits... It is not without reason that our dear fathers and prophets desired that music always be used in churches. Hence we have so many songs and psalms. There are undoubtedly many seed-grains of virtue in the human heart which are stirred up by music. I regard those with whom this is not the case as blockheads and senseless stones. For we know that the devil's music is something altogether hateful and unbearable. I am not ashamed to confess publicly that next to theology there is no art which is the equal of music. For it alone can do what otherwise only theology can accomplish, namely quieten and cheer up the soul of man - clear evidence that the devil, the originator of depressing worries and troubled thoughts, flees from the voice of music just as he flees from the words of theology. For this very reason the prophets cultivated no art as much as music in that they attached their theology not to geometry, nor to arithmetic, nor to astronomy, but to music, speaking the truth through psalms and hymns." Cf. Foreword to Georg Rhau's Collection, Symphoniae iucundae. Quoted in Walter E. Buszin's essay, entitled "Luther on Music," published in the January 1946 issue of the Musical Quarterly, G. Schirmer publisher; Luther's Saemmtliche Schriften, St. Louis Edition, XIV, 428-31 (W.E. Buszin); Anton, Karl, Luther und die Musik (Zwickau, 1928) 50-53 (W.E. Buszin); St. Louis Edition, XXIa, 1574 (W.E. Buszin).

John Calvin, Institutes of the Christian Religion, ed. John T. McNeill, trans. Ford Lewis Battles, 2 Vols., Library of Christian Classics (Philadelphia: Westminster Press, 1960), 3/14.

Icons should be distinguished from Idols. Idols are images that pretend to be absolute images of God. The biblical ban on images is on this, i.e. that people do not create images under the impression that they have now made an absolute image of God. Because we are sinfully inclined to want to be God ourselves, the result of such a creation is usually the misconception that we can now exercise control over this imaged, compacted God. According to Adorno the biblical ban on images does not want to veil God, but rather to reveal our sinful inclination. He also points out that the Jewish understanding of the image ban is not a total negation of all images, but of those that presume to be absolute 
example of such an icon of sound. The Hagia Sophia is a Justinian church which was built during 532-537, and repaired and re-consecrated in 562 after the devastating earthquake of 557. ${ }^{11}$ The architecture of this church is truly remarkable: it creates a space for multi-sensory experience of worshipping of the Transcendent.

This sacred space (also called chora) is constructed to encourage circular movement of the senses (also called choros). The idea is that the senses move forwards, upwards, following this circular environment. Sight (light shining through strategically placed windows), smell (burning incense), the touching of holy objects, and the tasting of the Eucharist, but also the reverberating of sound follow this circular pattern in the Hagia Sophia. The effect of entering this holy space is receiving the gift of wisdom (sophia), which in turn is a gift of grace (charis). Within this holy space, you receive life, new life, as you enter the breathing space of the Spirit (pneuma), and therefore receive new breath for life. ${ }^{12}$

Within this holy space, Christ comes to you through the living Voice of his Word; his Spirit rides the waves of sound; and salvation lurks in sonic spheres. In short: When entering this church, worshippers experience a type of iconographic interplay between spirit (pneuma), wisdom (sophia), space (choros), movement (choros), and grace (charis). In this sense the icon indicates breath (sound, pneuma) that is emptied into space, constituting it as holy space, as a chora being created in the circular movement of choros.

In all of this, sound plays a fundamental role. It has even been noted that sound emerges as the major factor in this movement, "forming and opening through voice a space of divine presence, of encounter and exchange: the choros of charis (circle of grace)."13 What the eyes cannot perceive, sound offers: a densely layered iconographic expression of salvation. ${ }^{14}$ It is indeed sounding salvation, in the double sense of the phrase: it is salvation that takes on human form; that grants, through grace, the kenotic experience of salvation via the paradoxical, temporal, mortal, delicate, and vulnerable instability of human voice - it is the

expressions of God. Cf. E.A. Pritchard, Bilderverbot meets Body in Theodor W Adorno's Inverse Theology. Harvard Theological Review (95:3) July 2002, 302. Icons, on the other hand, are expressions of the God who decided to become human, who corporeally intermingled with our existence, and in his inexpressible goodness accepted the nature, density, form and colour of the body. Icons are images of God in the flesh and as such a paradigm of, and window on, eternity. In icons there is always the paradox: they cannot portray God, and yet they portray God according to the paradox (wonder) of Christ - truly God and man. They can function as signs that point to bigger realities and can thus bring about awe for the invisible, and they can mediate the transition of faith between the visible and the invisible. Cf. M. Zibawi, Die Ikone. Bedeutung und Geschichte (Solothurn und Düsseldorf: Benziger, 1994), 25-33.

11. Still to be seen in present-day Istanbul.

12. Cf. Bissera V. Pentcheva, The Sensual Icon. Space, Ritual, and the senses in Byzantium (University Park, Pennsylvania: The Pennsylvania State University Press, 2010), 43-56.

13. Pentcheva, The Sensual Icon, 48.

14. Cf. the words of MCluhan and Powers: "Speech, before the age of Plato, was the glorious depository of memory. Acoustic space is a dwelling place for anyone who has not been conquered by the one-at-atime, uniform ethos of the alphabet. (...) There are no boundaries to sound. We hear from all directions at once." Marshall MCluhan/ Bruce R. Powers, The Global Village: Transformations in World, Life and Media in the $21^{\text {st }}$ Century (New York, 1989), 36f. 
Spirit breathing upon us; but it is also the call to our spirit to breath with the Spirit, literally sounding salvation through our vocal chords and human capacities.

The Word thus becomes Sound; divine presence reverberates as sounding salvation in our midst, taking on human vulnerability and frailty, but also using these human conditions as medium of life. Pneuma is imparted to matter; life is breathed into dust. The Spirit breathes out, taking our breath away, but also giving it back, amplified, sanctified. But then the Sound of the Spirit's breath also fades away, back into silence and stillness. The sounding of salvation is not just about a never-ending, uninterrupted monotony of sound; it is life-giving within the pulsating and reverberating spaces between sound and silence.

\section{The Sounds of Silence}

Sound without silence is monotonous and therefore boring; silence without sound is the abyss of nothingness. Sound needs silence, and silence calls for sound. Silence without sound is deaf; sound without silence is deafening. We need the sounds of the tick-tock of the clock to make sense of silence (i.e. that we are living within the co-ordinates of time and space); but the tick-tock of the clock must also be separated by pauses, by silences, for the same reason to make sense of the contingencies of our existence.

It is clear that musicians know about this intrinsic connection between silences and sounds (music). Empty bars or parts of bars occur in virtually every musical composition; rests are an inseparable part of any piece. On a more modest and subtle level, silences mark the transition from one musical sentence to the next by way of caesura. Silence demarcates the beginning and the end of a piece of music. "To focus on the phenomenon of musical silence is analogous to deliberately studying the spaces between trees in a forest: somewhat perverse at first, until one realizes that these spaces contribute to the perceived character of the forest itself, and enable us to speak coherently of "dense" growth or "sparse" vegetation. In other words, silence is not nothing. It is not the null set. Silence is experienced both as meaningful and as adhering to the sounding position of the musical object." ${ }^{15}$

In musical theory, silence is not always referred to as the point where musical sounds actually cease to exist. Moments of silence are experienced during sustained fermates, extreme pianissimos, or when a complex harmony dissipates into a sparing use of the tone material. One becomes aware of silence in music that "sounds from afar", usually indicated by the instruction "come da lontano". A great number of compositions by Russian composer Alfred Schnittke for instance open and close with scarcely audible sounds. His music resonates between the not-yet-audible and the no-longer-audible. It gives the impression that his music is there long before the listener can hear it and continues to resound long after the listener has registered the last tones. Through this "non-ceasing" music, which resounds beyond the limits of its audibility, silence acquires a different form of musical Dasein. ${ }^{16}$

15. Thomas Clifton, “The Poetics of Musical Silence”. The Musical Quarterly 62 (2), April 1976, 163.

16. Clifton, "The Poetics of Musical Silence”, 163. 


\section{African Rhythm}

Africa has its own rhythms of sounds and silences, its own rhythms of life. Interestingly, Western traditions with their ocular and linear approaches are more orientated towards music as melody (individual steps and parts harmoniously combined into a finished performance piece), whilst in African oral cultures it is rhythmical and even poly-rhythmical structures that create discontinuity in the musical score. ${ }^{17}$

The intention of African rhythm is however not (as the word "discontinuity" may suggest) to "disrupt" the flow of the music; rather it means that the emphasis is not necessarily on melodious coherence, but on the impetus for life that rhythm can provide. In African spirituality singing is all about bringing people back to the rhythms of life. Singing expresses and underscores the life-cycle - therefore Africans sing from the cradle to the grave. Music condenses time; it brings those who sing back to their origins, but also gives meaning to the present as sacred time. ${ }^{18}$

In this sense, music is not a thing, an object, it is an action. Perhaps we should follow the cue of the Dutch liturgist Mirella Klomp and not use a noun to refer to music, but rather a form of verb: musicking. ${ }^{19}$ Music is performed - not only on a stage by professional musicians, but by ordinary people, in everyday life. In Africa, where we do not have such a clear distinction between the sacred and the secular, sound is inherently spiritual, the sacred is inherently sonic - "both sound and the divine permeate every imaginable part of life."

The power of sound lies not only in its ability to give meaning to life, but also in that it represents one of the major African responses to the impact of life as a whole. Music - sound - is a social happening par excellence. Sound performance is as important, and normal, as eating and sleeping, as walking and talking. Sound is not so much performed for an audience, but rather with a community - as an expression of the rhythms of life. ${ }^{21}$ Well-being resides inter alia in finding one's place within these rhythms, in entering these acoustic spaces of rhythmic well-being.

On the contrary, it would seem that in some Western traditions the social aspect of "musicking" carries less weight than its technical or aesthetic aspects. Religion, and consequently sacred music, is normally performed at appointed times and in designated places - contrary to African "musicking" of life as a whole. It has been said that late modern music culture is basically auditive in nature, and although music seems to be omnipresent (IPods, MP3-players, Web Radio, Cell phones, etc.), it still represents a culture of "easy listening" as an individualised activity. Although music has become more accessible to the general western

17. Archwells M. Katani, Traditional Malawian Choral Music: A Liturgical-Critical Study within the Church of Central Africa Presbyterian (CCAP) - Nkhoma Synod. Unpublished DTh. University of Stellenbosch, 2008: 115.

M.E. Eliade, The Myth of the Eternal Return: Cosmos and History (Princeton: Princeton University Press, 1971), 151-152.

19. Klomp, The Sound of Worship, 42.

20. Klomp, The Sound of Worship, 48. Although Klomp is referring to research done amongst West Africans, the trends are applicable to a general African understanding of music.

21. Klomp, The Sound of Worship, 49. 
public by means of sound pictures of music (as opposed to score sheets), the socializing power of music seems to be fading; sound has become a solo show. ${ }^{22}$

It is this socializing power of sound that is brilliantly depicted in the Swedish film by Kay Pollak $A s$ it is in Heaven in which in one scene the pastor's wife accuses the church of inventing and sustaining a specific understanding of sin for the sake of "staying in business". In a moment of long overdue honesty she confronts and profoundly shocks her husband by openly stating her secret belief that the liturgy of the church has become a tool to manipulate the concept of sin and consequently people's constant feelings of guilt in order to remain in control, and so-doing exert power over them. In effect she protests against the way in which the liturgy enslaves, instead of frees; the way in which it muzzles life, instead of affirming and gratefully celebrating it. In a sense she cries out for a fundamental reshaping and reframing of the liturgy into a liturgy that celebrates the gift of life and freedom, incorporating all of humanity - "as it is in heaven". 23

A liturgy (or: music, sound) "as it is in heaven" does not imply that we are separated from this world and whisked away to heaven. It is not an abstraction from real life, but articulates metaphorically that this life should be viewed from a radically different perspective. After all, liturgy means to enter, with God, the streets and market-places, and consequently to be repositioned within the rhythms of existential reality. ${ }^{24}$ In the film $A s$ it is in Heaven the network of relationships (as represented in the community of the choir), as well as the understanding of the church (ecclesiology) and its practices of liturgy, are fundamentally challenged. Established God-images are transformed. This takes place via the body (singing, breathing, movement), in other words within the context of a leitourgia that is fully situated in this life.

Clearly sound carries fundamental religious (and theological) weight. This understanding of sound however operates on more than merely a cognitive level. In the African lullaby (Tula Tu Tula baba...) the words (as bearers of cognitive contents) are important, but they are also primarily the vehicle that bears the sounds of soothing; that facilitates the tones of nurturing. Although the baby does not cognitively comprehend the "meaning" of the words, the "meaning" of the song is understood.

This is not only true for infants: in the Hagia Sopbia the so-called "brightness" of sound comes with the concomitant blurring of the sung words. "The reverberations oscillating in space created delayed echoes, which in turn eroded the clarity of the original expression. Yet they also gave an otherworldly experience of a mellifluous resounding sound. It is not intelligibility that is given priority in the Byzantine chant, but radiance, the presence of intensified reverberations." 25

\footnotetext{
22. Klomp, The Sound of Worship, 65-66.

23. Cf. Johan Cilliers, As it is in heaven? Reflections on liturgical reframing. Scriptura. International Journal of Bible, Religion and Theology in Southern Africa. 102 (3), 2009: 509-517.

24. C. Plantinga; S.A. Rozeboom, (eds.). Discerning the spirits. A Guide to Thinking about Christian Worship Today (Grand Rapids, Michigan/ Cambridge, U.K.: Eerdmans, 2003), 3.

25. Pentcheva, The Sensual Icon. 52.
} 


\section{Fides quaerens sonum (faith in search of sound)}

This "acoustical sounding of salvation", corresponds with an understanding of faith seeking sound (fides quaerens sonum). It is about acoustics as a spiritual (pneumatological) expression of life; acoustics as beautification of life; acoustics as the existential expression and articulation of a belief system through sound. The specific rhythms of a culture, in other words cultural sounds grouped together and separated by silences, by acoustic spaces and pauses, become a medium of salvation; in other words a medium of life and well-being. ${ }^{26}$

Salvation and well-being are related to one another in a dynamic manner. This relationship could be called the healing of life. Although the notions are not identical, they cannot be separated either. Salvation is a theological concept, referring to the act of God's grace. Healing and well-being can be understood in psychological and physical terms, but it must also be said that salvation can and does have implications for healing and well-being, i.e. psychological and physical categories. Perhaps it is best to state here, in theological terms, that the tensions between these notions are eschatological in nature. ${ }^{27}$

This eschatological tension entails that the healing of life follows when seemingly irreconcilable realities are connected in such a way that these realities are in fact transcended, and something new is anticipated. However this anticipated reality already influences the present realities, and in fact creates a "new" reality, a novum, which is far more than just a restoration of the old; it is something new that takes the place of the old. In theological (eschatological) terms we could call this hope. ${ }^{28}$

Musicking as an articulation of life, and evaluated theologically, could indeed be called a performance of hope. Music has this remarkable ability to transcend, and to anticipate a novum. Many of the Negro Spirituals achieved exactly this: they transcended stark realities in such a manner that a utopian spirit was created, a spirit that did not flee or escape from those stark realities in a superficial or sentimental manner, but faced them, and in doing so, transcended them in anticipation of new and better realities.

Consider for instance the well-known song Swing Low, Sweet Chariot, a historic American Negro Spiritual, composed by Wallis Willis. ${ }^{29}$ The chorus and first verse speak of a future ("home"), but also of the band of angels that are (already) "coming for to carry me home."

Swing low, sweet chariot

Coming for to carry me home,

Swing low, sweet chariot,

Coming for to carry me home.

I looked over Jordan, and what did I see

Coming for to carry me home?

26. Cilliers, Faith in search of sound, 24.

27. Cf. for a detailed discussion, Daniël Louw, Cura Vitae. Illness and the healing of life (Wellington: Lux Verbi.BM, 2008), 85f.

28. Cf. Johan Cilliers, Liturgy as space for anticipation. HTS Theological Studies/Teologiese Studies 2011; 67 (2): $1-7$.

29. The earliest known recording was in 1909, by the Fisk Jubilee Singers of Fisk University.

TD, Special edition, 10(2), November 2014, pp. 34-46. 


\section{A band of angels coming after me, Coming for to carry me home.}

The rest of the song articulates the burdens of life -"sometimes I'm up and sometimes I'm down" - while living with the hope, with the knowledge that: "still my soul feels heavenly bound." Why? Because the angels are "coming for to carry me home!" This is sounding, and re-sounding salvation within the in-between (eschatological) spaces of journeying and coming home. This is hope in action within reality par excellence.

The same can be said of many examples of music, for instance the iconic works of Beethoven. In his famous opera Fidelio (10) we hear these words about the liberation of Florestan sung by different characters:

Don Fernando: Du schlossest auf des Edlen Grab, jetzt nimm ihm seine Ketten ab; doch halt, euch, edle Frau, allein, euch ziemt es, ganz ihn zu befrein.

Leonore: $O$ Gott, o Gott, welch ein Augenblick.

Florestan: O unaussprechlich süsses Glück!

This liberation from chains signifies a decisive moment of liberation, and consequently a moment of restored human dignity. Like the Negro Spirituals, Beethoven's music does not try to escape from the screams and cries of life; it does not fear the anxieties and chains of our existence. On the contrary, it faces it, opens it up, reveals it, in order to transcend it in anticipatory celebration of the novum. This music does not represent a false romanticising of life, neither is it a-romantic; it does not articulate sentimentalism, but rather transcends, anticipates, and celebrates. It is a musical performance of the prolepsis that is already present as a novum. Again, theologically speaking, this is what we call hope. ${ }^{30}$

Nowhere are the connections between music and hopeful anticipation expressed more movingly than in the writings of Victor Frankl. He recalls how the most terrible moments in Auschwitz were made bearable by sporadic aesthetic ${ }^{31}$ experiences, like for instance the

The comments of Ernst Bloch on the final scenes of Beethoven's Fidelio are interesting. Bloch evaluated the music of Beethoven, and this piece in particular, as an iconic expression of the hope for freedom. According to him, this opera transcends its historical settings to communicate freedom and hope across the ages. He states: "Every future storming of the Bastille is implicitly expressed in Fidelio." Ernst Bloch, Essays on the Philosophy of Music, trans. Peter Palmer (Cambridge: Cambridge University Press, 1985), 243. Paul Robinson formulates this connection between freedom, hope, and the music of Beethoven as follows: "At the ideological centre of Fidelio stands the abstract idea of freedom. It is not expressly connected with any particular political movement or social group, nor is it elaborated into particular freedoms such as freedom of speech, religion or the press. Rather it is freedom tout court." Paul Robinson, Ludwig van Beethoven: Fidelio (Cambridge: Cambridge University Press, 1996), 75.

31. The notion of aesthetics should not be misunderstood as only pertaining to the superficiality of prettiness and inoffensiveness. There is something like "a beautiful representation of ugliness." Aesthetics also include what Nietzsche called "the beautiful chaos of being." This is particularly true of faith and theological aesthetics. The beauty of God is often revealed under circumstances of chaotic disproportionateness, which can be viewed as disturbing ugliness. But they can also be viewed as a different kind of "beauty". Romanticised notions of harmonious proportion cannot for instance be used to describe the cross. The cross can only be understood as "beauty" within the paradoxical and tentative space and tension between chaos and order. Only in a theological sense - or: through faith (fides) - can "ugly" be seen as "beautiful", or as chaos that is en route to a healed, i.e. radically different, form of proportion. As a matter of fact, the ugliness of the cross is the strange "beauty" of God par excellence, 
second night that he was in Auschwitz, and was woken up by the sound of a violin playing a mournful tango. He thought of someone who had to celebrate her birthday in a cell block a few hundred metres away from him - his wife. In his imagination he stood up and danced with her ... and the rhythm of life and hope infiltrated even Auschwitz. ${ }^{32}$

It is quite amazing that we have a word in Africa that signifies the transcendental feeling induced by music - a word that has no equivalent in the English language. It is the isiXhosa word Ihlombe, which expresses the ability of music to transport people to a state of overwhelming joy in which they become so acutely moved that they are compelled to stand up and participate - through dancing or otherwise. In the Zulu language Iblombe translates into applause. This is truly the "magic of musicking" - it faces reality to change reality, to applaud (a new) reality. The magic of musicking prompts applauding and dancing the novum.

Salvation comes to us in the rhythms of our lives, i.e. in the liminal spaces between the sounds and the silences that make up these rhythms. It is precisely thanks to this in-between (i.e. eschatological) character of salvation, that it comforts us - because it corresponds with the realities of our fragmented existences. The Word becomes Sound, seeking out the media of vulnerable bodies and vocal chords, and in doing so, soothes us. We hear human sounds, but these sounds transcend and are transcended to become divine Sounds through the iconic enablement of the Spirit. These transcended and transcending sounds anticipate the new, the unthought-of possibilities or alternatives. In this way even the destructive sounds that often surround us, lose their demonic disposition. Let me illustrate the latter by means of two art works:

Firstly, the famous painting by Edvard Munch entitled The Scream (sometimes also called The Cry). ${ }^{33}$ The Norwegian word for "scream" - also the original title of the painting - is "Skrik". This is an even stronger expression than "scream" or "cry". It denotes the overwhelming fear of threat, the devastating emotions of an uprooted existence, and the immediacy of the impact of terror. Obviously, there is no sound, but the visual depiction is so strong that you can actually "hear" the sound in the mind's ear, so to speak. In the painting it is not the soothing sounds of salvation that you "hear", but the anguished cry of despair and death. We tend to think that seeing is the major sense. But you cannot actually "see" this painting before you have heard a scream - an incessant scream filled with terror and despondency. Visual perception only takes place via an acoustic one.

because this ugliness lives within the tension and paradox of cross and resurrection. Cf. the discussions by Renate Reschke, Schön/Schönheit, Ästhetische Grundbefriffe 5 (Stuttgart, Weimar: J.B. Metzler, 2010), 416f; Friedrich Nietzsche, Die fröhliche Wissenschaft (1882), in: Nietzsche (KGA), Abt. 5, Bd. 2 (1973), 201; Johan Cilliers, Fides Quaerens Pulchrum: Practical Theological Perspectives on the Desire for Beauty. Scriptura: International Journal for Bible, Religion and Theology in Southern Africa 2011; 3 (108): 257-268; Paul Evdokimov, The Art of the Icon: A Theology of Beauty (New York: Oakwood Publications, 1996), 309f.

32. Victor E. Frankl, Ein Psycholog erlebt das Konzentrationslager. Zweite Auflage. (Wien: Verlag für Jugend und Volk, 1947), 56-60.

33. This image was originally displayed in Berlin in 1893 as part of a series of six paintings, called: "Study for a Series Entitled 'Love". The original version of The Scream is now located in Norway's National Gallery in Oslo. 


\section{Cilliers}

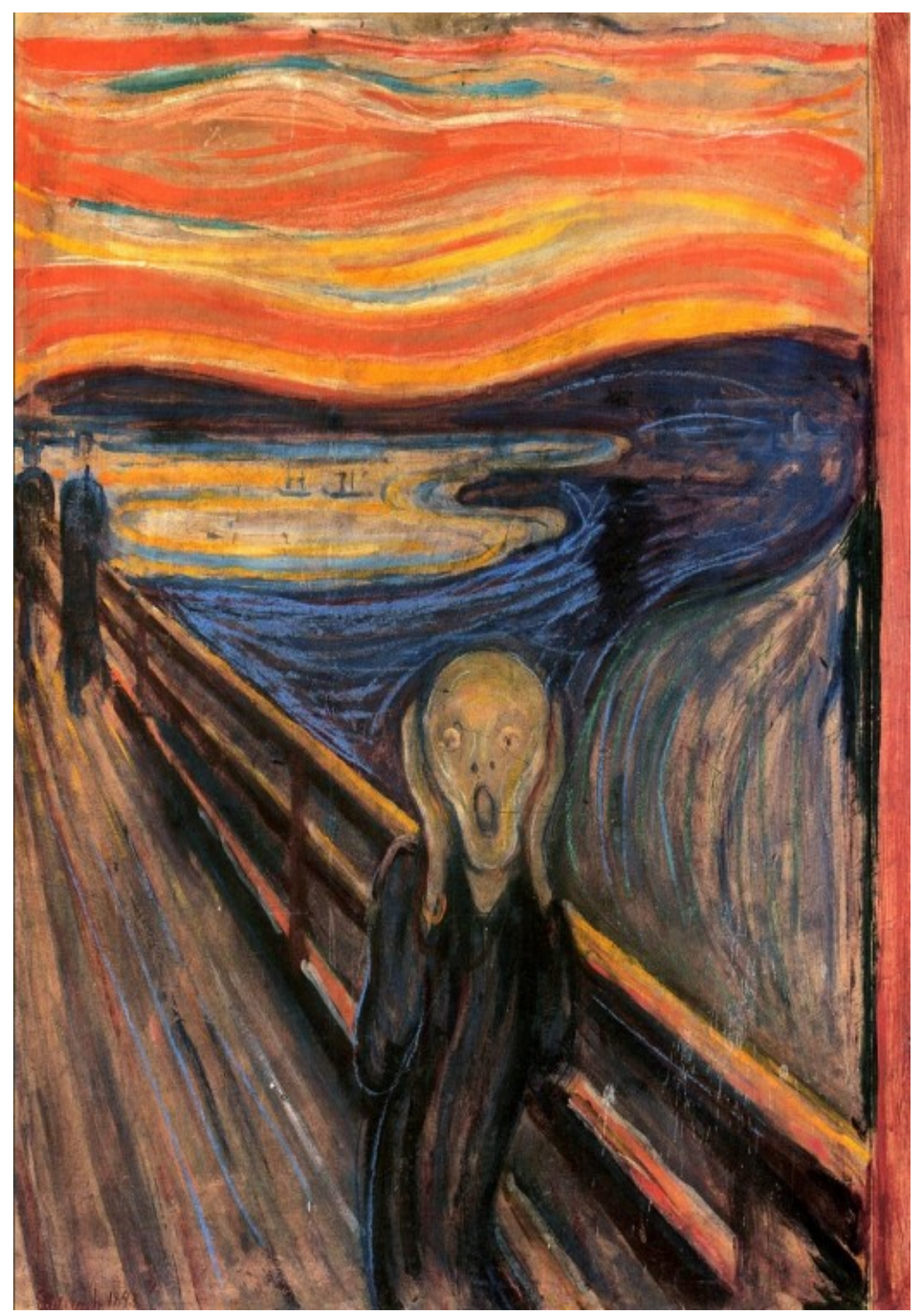

The brush strokes in the tempestuous background cause the scene to appear to swirl, giving it a sense of motion. We also have a feeling of sensory movement, a type of choros if you wish, in which the eye is forced to move restlessly, in keeping with the mood of the painting. The auditive aspect, the rising and swelling of the sound seems to be the strongest impulse, but in this particular circular sound, this circular scream, there is no charis, no grace.

It is widely held that in this painting Munch expressed the inner anxiety he experienced as an individual due to circumstances like bouts of depression, his failing health, his loss of belief, etc. Therefore the painting has been labelled as existentialist in nature, even as one of the first true expressionist paintings. ${ }^{34}$ In keeping with this genre of art, the painting depicts the expression of inner experience rather than a realistic portrayal, seeks to express the subjective emotions and responses that objects and events arouse in the artist rather than an "objective"

34. Cf. Adam Butler, Claire Van Cleave, Susan Stirling, The Art Book (London: Phaidon, 1996), 331. 
reality. Munch's painting does not show a realistic visual interpretation of reality; it is an abstract image, based on his inner, troubled feelings, and attempts to convey his most intimate and terrifying emotions. The emotive distortions and exaggerated colours are used to achieve maximum expressiveness. ${ }^{35}$ In January 1892 Munch wrote the following in his diary a description of his feelings which seems to fit the depiction of The Scream:

"I was walking along the road with two friends. The sun was setting. I felt a breath of melancholy suddenly the sky turned blood-red. I stopped, and leaned against the railing, deathly tired - Looking out across the flaming clouds that hung like blood and a sword over the blue-black fjord and town. My friends walked on - I stood there, trembling with fear. And I sensed a great, infinite scream pass through nature."36

However one wishes to interpret this iconic painting, it does seem to scream out, figuratively, the anguish of a tormented world. It is a sound that does not save, but shatters; that does not heal, but hurts; that does not sooth, but suffers.

It reminds one of another sound, illustrated in the disturbing and shocking sculpture by the Brazilian artist Guido Rocha, entitled The Tortured Christ (1975). At first glance, no, at first hear, it sounds like exactly the same scream as the one coming from Munch's tortured figure on the bridge. This sculpture by Rocha could just as well have been called The Scream. ${ }^{37}$

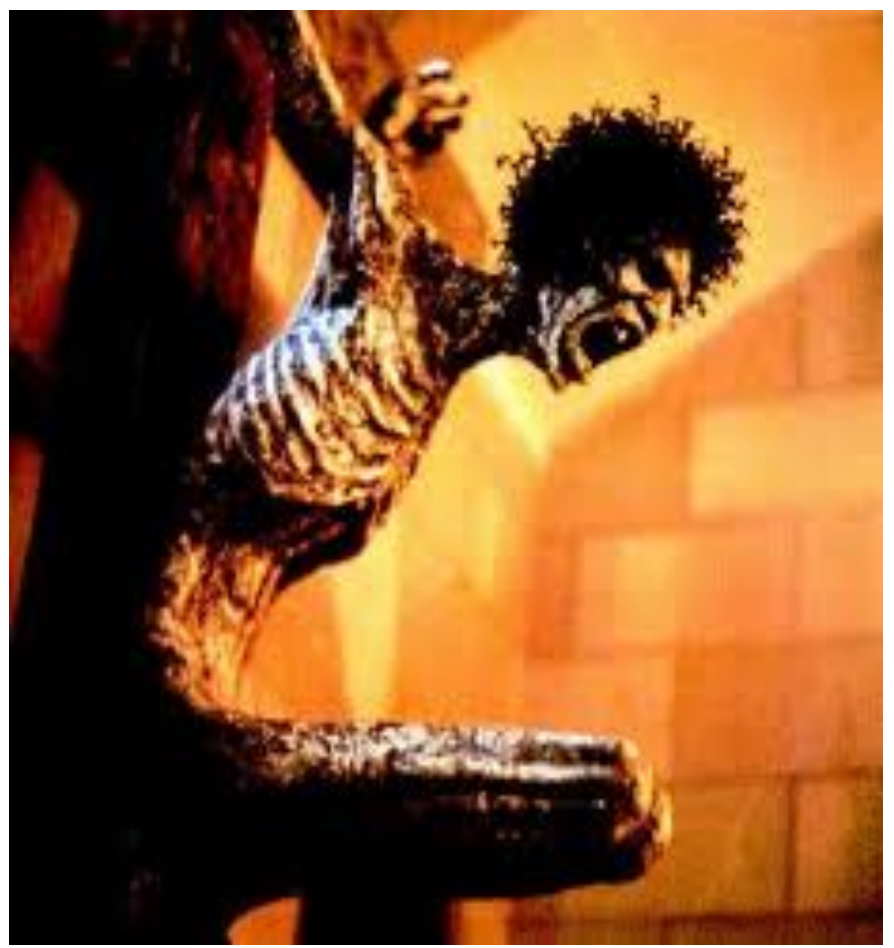

35. Butler, Van Cleave, Stirling, The Art Book, 331.

36. The Private Journals of Edvard Munch. We are flames which pour out of the earth. Edited and translated by J. Gill Holland (Madison, Winsconsin: The University of Winsconsin Press, 2005), Entry: Nice 22.01.1892.

37. Cf. Hans-Ruedi Weber, Und kreuzigten ihn. Meditationen und Bilder aus zwei Jabrtausenden (Göttingen: Vandenhoeck und Rupprecht, 1980), 40-41.

TD, Special edition, 10(2), November 2014, pp. 34-46. 
But it is, in fact, a different kind of scream; a different Sound that we hear here. At certain levels it does reverberate with Munch's Cry, being a Sound unsanitized by layers of euphemistic theology, unvarnished with coats of sentimentalism, not muffled by centuries of pietism. It is - like that of Munch - the crude Sound of death - coming from the vulnerability of a human vocal cord: My God, my God - why have you forsaken me...? ? $^{38}$ In Munch's Scream we hear no literal words; we are left with our imaginations, with "hearing" in our mind's ear. In the Crucified's Cry, the words are intelligible - they were reported in Scripture - but the sound also extends far beyond cognitive contents.

At first hear the two Screams sound the same, and yet there are fundamental differences. The Cry from the Crucified's mouth is the Sound of Salvation - because this Cry also articulates other words: It is completed (tetelesthai, from the root word telos). ${ }^{39}$ The Crucified dies, cries out loud, and breathes out his last breath (pneuma). ${ }^{40}$ This last breath grants us breath; graces us with the gift of (new) life. This last breath does not deny the Scream of Munch, in fact, it amplifies it. The scream from the cross takes up the scream of Munch - and all other cries of terror and trial - into the choros of charis, the circle of grace. No longer is the circle one of eternal chaos; it now becomes the life-giving circle of grace, reverberating on the threshold (Munch's bridge) between heaven and earth, indeed, between heaven and the hell of all Godforsaken spaces.

It may not sound like a soothing lullaby, but it is music to our ears.

38 . Matthew 27:46.

39. John 19:30.

40. Matthew 27:50. 